( А. П. Киричок, асистент, КПІ ім. Ігоря Сікорського, Київ, Україна

\title{
НАЧЕРКИ З РОЗВИТКУ ДОСЛІДЖЕНЬ У ГАЛУЗІ КРИЗОВИХ КОМУНІКАЦІЙ
}

Статтю присвячено огляду напрацювань у галузі кризових комунікацій. Здійснюється огляд основних складників цього поняття та досліджень, які проводилися, починаючи від виникнення кризових комунікацій.

Першу частину присвячено аналізу широкого спектру дефініцій поняття «кризова комунікація» та її складових частин. У другій частині автор робить огляд напрацювань, які здійснювались у напрямку дослідження кризових комунікацій. Третя частина звертає увагу на дослідження суміжних понять, пов'язаних з кризовими комунікаціями. В кінці статті автор аналізує етапи становлення кризових комунікацій. У статті ставиться акцент на дослідженні всіх складників кризово-комунікаційного реагування. Звертається увага та детально описуються всі етапи боротьби з кризою (докризова, кризова та посткризова фази). Автор робить висновки та окреслює перспективи досліджень.

Ключові слова: кризові комунікації; антикризовий PR; ризик-менеджмент; зв'язки з громадськістю; превентивне реагування; аналіз середовища; антикризове управління; проблемний менеджмент.

\section{Постановка проблеми}

Останні тридцять років інтерес до організаційної кризи спонукав науковців і практиків галузі менеджменту і комунікацій до дослідження кризових комунікацій.

Попередження кризи спрямоване на уникнення негативного резонансу в ЗМІ; воно відображає комунікативні аспекти кризи. Можемо стверджувати, що навіть одна година, втрачена дарма під час кризи, може коштувати дуже дорого.

\section{Результати проведених} досліджень

Існує досить велика кількість визначень поняття «криза» [1]. У деяких визначеннях за основу беруть помилки, яких припускається організація. Інші ж акцентують увагу на заходах з управління, які виходять за рамки звичайних або загальноприйнятих процесів управління. Деякі $з$ них підкреслюють критичний стан ситуації та напруженість, інші - неналежний контроль, невизначеність, порушення законодавства, етичних норм та інші зловживання.

(ㄷ) $2016 \mathrm{p}$. 
Однією з головних тем у кризі є питання відповідальності, бажання та здатність організації відстоювати свій імідж. Сюди можемо віднести і правовий аспект діяльності компанії. Варто зазначити, що антикризова діяльність має попереджати цільові групи про можливий ризик і наближення кризи.

Науковець Т. Кумбс із Коледжу комунікацій Університету Центральної Флориди запропонував своє бачення того, яким повинно бути визначення кризи. Він зазначив, що люди можуть помітити кризу лише частково, оскільки вони бачать тільки верхівку айсбергу. «Кризу можна розглядати як сприйняття події, яка загрожує важливим очікуванням учасників та може вплинути на діяльність організації. Кризи значною мірою відносяться до сприйняття. Якщо учасники вірять у те, що криза є, це означає, що організація перебуватиме в ній, поки вона не доведе учасникам процесу і громадськості протилежне» [2, C. 100].

Це визначення не цілком відображає ситуацію у стані інформаційної або гібридної війни, яка передбачає довготривалу потужну системну кризу і спрямована як на внутрішню, так і на зовнішню аудиторію.

У ході наукової роботи було знайдено багато досліджень про те, як організація повинна комунікувати під час кризи. Деякі науковці стверджують, що більшість кризових досліджень акцентує увагу на кризі в окремій організації, а не на тому, як вона впливає на громадськість [3].

Досить багато наукових праць присвячено управлінській скла- довій під час кризи. Показовим $\epsilon$ дослідження, пов'язане із сексуальним скандалом в римськокатолицькій церкві [4].

У ході цього дослідження було проаналізовано антикризову риторику католицької церкви США, постраждалих від сексуальних домагань та суспільні думки релігійних осіб.

Деякі науковці намагаються виокремити антикризове планування у три етапи: передкризове, кризове та посткризове, і таким чином вивчають дослідження, пов'язані з кожною стадією [2]. Т. Кумбс з цього приводу говорить наступне: «Те, наскільки добре ми розуміємо ці стадії як дискретні, але взаємозалежні події (пункти аналізу) та знаємо, що кожна вимагає як запобігання, так і реакцію на кризу, може покращити теоретичні та практичні аспекти у галузі кризових комунікацій» [2].

Під час огляду досліджень у галузі кризових комунікацій, важливо надати визначення ключовим термінам кризи для того, щоб окреслити межі досліджень. Основними поняттями тут постають такі: криза, антикризове управління і кризові комунікації. Ці три нерозривно пов'язані між собою дефініції повинні розглядатися в прогресії від кризи до антикризового управління і кризових комунікацій. Для того, щоб оперувати ними, необхідно визначити, що означає кожне 3 них. Існує велика кількість визначень поняття «криза» [2]. Наприклад, деякі науковці стверджують, що це - «головне явище 3 потенційно негативним результатом, що впливає на організацію, компанії, всю галузь, а 
також громадськість, продукцію, послугу або імідж. Воно унеможливлює діяльність організації та становить загрозу її існуванню» [5]. У іншій дефініції йдеться про те, що «це не обов'язково погане явище. Це може бути радикальна зміна благ, як на краще, так і гірше» [6, С. 5].

Посилаючись на третє визначення, варто зазначити, що це «подія, яка потенційно може впливати на всю організацію. Таким чином, якщо щось зачіпає лише невелику, ізольовану частину організації, то це не може бути серйозною кризою. Для того, щоб сталася серйозна криза, вона повинна бути важким тягарем для життя людей, майна, фінансових доходів, репутації, а також загального стану благополуччя організації» [7, С. 25-34]. Також можна стверджувати, що це «переломні моменти в житті організації» [8]. I це далеко не повний перелік дефініцій поняття «криза».

Антикризове управління може бути визначене як «сукупність факторів, спрямованих на боротьбу з кризами і зменшення нанесених фактичних збитків» [9, С. 5]. Крім того, однією із головних функцій антикризового управління $€$ запобігання або зменшення негативних наслідків кризи та захист організації від руйнувань [10, С. 4].

Антикризове управління це багатоаспектний процес, який включає в себе превентивні заходи, плани з урегулювання криз, посткризовий аналіз і роботу над помилками. Його можна поділити на три етапи: докризове, кризове та посткризове. До докризової належить діяль- ність щодо запобігання криз та підготовка до антикризового управління. Антикризове реагування $є$ відповіддю на кризу, що триває. Посткриза - це діяльність з вивчення причин кризи та самого процесу кризової ситуації [9].

Кризові комунікації можна визначити як збір, обробку i поширення інформації, необхідної для вирішення кризової ситуації. У докризовому періоді їх функція полягає у зборі інформації про можливі ризики для організації, прийняття рішень 3 управління потенційними кризами, а також навчання людей, які братимуть участь у антикризових заходах. Навчання включає в себе членів кризової групи, кризових представників і будь-яких осіб, які будуть допомагати у подоланні кризи.

Кризові комунікації передбачають збір та обробку інформації для командного прийняття рішень, а також створення і поширенням «кризових» повідомлень особам за межами команди. Посткризовий період включає аналіз зусиль антикризового управління, ведення діалогу про необхідні зміни для окремих осіб, а також, за необхідністю, надання «кризових» повідомлень. Кризові комунікації зосередилися на кризі та реагуванні на неї, а також на посткризовій діяльності організації. Антикризове реагування $є$ дуже важливим елементом як у діяльності компанії, так і для суспільства, яке перебуває в епіцентрі кризи. Наприклад, неправильні антикризові заходи роблять ситуацію ще гіршою. 
Кризові комунікації є одним iз найважливіших елементів ефективного антикризового управління. Проте, будь-яке обговорення кризових комунікацій повинно починатись 3 огляду витоків антикризового управління в більш широкому контексті для кризових комунікацій.

У 1986 році науковець з Бостонського коледжу комунікацій С. Фінк опублікував свою працю під назвою «Планування неминучого» [11]. У монографії вперше описуються всі тогочасні аспекти антикризового управління, а також суміжні галузі. Фінк стверджує: «Антикризове управління не могло з'явитися 3 нізвідки. Коріння антикризового управління можна знайти в надзвичайних ситуаціях і ліквідації наслідків стихійних лих» [11].

Саме за допомогою вивчення надзвичайних ситуацій i ефективних варіантів ліквідації наслідків стихійних лих досліджувались шляхи запобігання різноманітним інцидентам та антикризове реагування. Наукові статті в галузі антикризового управління вперше було опубліковано в Міжнародному журналі з питань надзвичайних ситуацій та стихійних лих. Крім того, є помітним сильний акцент на антикризовий складник у протоколі публікацій журналу «Непередбачені ситуації і антикризове управління». Вивченням антикризових заходів під час стихійних лих досить детально займався науковець з Університету Каліфорнії І. Карантеллі [12]. С. Фінк також був одним з перших, хто вивчав кризи, поділяючи їх на етапи. Модель Фінка складається з чотирьох етапів: початковий
- 3'являються тривожні ознаки кризи; етап загострення - виникає криза; етап відновлення може включати в себе страх перед кризою; і розв'язання кризи - організація повертається до функціонування в звичайному режимі [11]. Фінк також пропонував модель розвитку кризи.

Іншим науковцем було розроблено покрокову триступеневу модель процесу антикризового управління: управління кризою - її виявлення; активна криза - подія відбувається і потрібно вживати певних заходів; кризова легітимізація - комунікативна відповідь надається ЗМІ та уряду [13]. Існує також і петля зворотного зв'язку від легітимації кризи до врегулювання кризи. Науковець Д. Сміт із університету Денвера почав виходити за рамки власне кризового процесу, розглядаючи також зусилля антикризового управління.

Науковець з Університету Південної Каліфорнії $Є$. Мітрофф пропонує модель з п'яти антикризових етапів: виявлення ознак кризи - необхідно виявити загрозу і вжити превентивних заходів; моніторинг і профілактика активний пошук і зменшення факторів ризику; відновлення захисної оболонки - дії направлено на нейтралізацію кризи під час її протікання; відновлення зусилля направлено на те, щоб повернутися до нормальної роботи; і навчання - люди розглядають роботу антикризового управління і навчаються протидіяти кризі [14]. Мітрофф вважає, що процес антикризового управління - більше, ніж просто 
управління під час кризи. В цілому, антикризові моделі відображають процес управління в надзвичайних ситуаціях: пом'якшення, готовність, відповіді, і відновлення [15]. Навчання науковець виділяє як окремий етап. Процес антикризового управління може бути організований навколо трифазової моделі: докризова, кризова, і посткризова фази. Докризова включає в себе виявлення сигналу, профілактику і підготовку. Безпосередньо криза охоплює визнання події і реагування на неї. Посткризова фаза зосереджується на дії після закінчення кризи, направлені на повернення до нормальної діяльності [9].

\section{Висновки}

Кризова комунікація є специфічною сферою досліджень у галузі зв'язків з громадськістю, яка продовжує активно розвиватись. Можна зі впевненістю сказати, що тема антикризового менеджменту стала домінуючою в дослідженнях зв'язків з громадськістю. Незабаром ми зможемо спостерігати ситуацію, коли кризові комунікації стануть практично самостійною галуззю знань, мінімально залежною від зв'язків з громадськістю. Кризова комунікація нерозривно пов'язана з трьома іншими ключовими сферами PR: ризиковою комунікацією, проблемним менеджментом та репутаційним менеджментом. Тому дуже важливо, щоб цю проблематику досліджували в єдиному контексті.

\section{Список використаної літератури/References}

1. Heath, R. L. \& Millar, D. P. (2004). A rhetorical approach to crisis communication: Management, communication processes, and strategic responses. In D. P. Millar \& R. L. Heath (Eds.), Responding to crisis: A rhetorical approach to crisis communication (pp. 1-17). Mahwah, NJ: Lawrence Erlbaum Associates [in English].

2. Coombs, W. T. (2009). Conceptualizing crisis communication. In R. L. Heath \& H. D. O'Hair (Eds.), Handbook of crisis and risk communication (pp. 100-119). New York: Routledge [in English].

3. Waymer, D. \& Heath, R. L. (2007). Emergent agents: The forgotten publics in crisis communication and issues management research. Journal of Applied Communication Research, 35, 88-108 [in English].

4. Boys, S. (2009). Inter-organizational crisis communication: Exploring source and stake-holder communication in the Roman Catholic clergy sex abuse case. In R. L. Heath, E. L. Toth, \& D. Waymer (Eds.), Rhetorical and critical approaches to public relations (pp. 290-300). New York: Routledge [in English].

5. Fearn-Banks, K. (1996). Crisis communication: A casebook approach. Mahwah, NJ: Lawrence Erlbaum Associates [in English].

6. Friedman, M. (2002). Everyday crisis management: How to think like an emergency physician. Naperville, IL: First Decision Press [in English].

7. Mitroff, I. I. \& Anagnos, G. (2001). Managing crises before they happen: What every executive and manager needs to know about crisis management. New York: AMACOM [in English].

8. Regester, M. (1989). Crisis management: What to do when the unthinkable happens. London: Hutchinson Business [in English]. 
9. Coombs, W. T. (2007). Ongoing crisis communication: Planning, managing, and responding (2nd edn.). Los Angeles: Sage [in English].

10. Coombs, W. T. (1999). Ongoing crisis communication: Planning, managing, and responding. Thousand Oaks, CA: Sage [in English].

11. Fink, S. (1986). Crisis management: Planning for the inevitable. New York: AMACOM [in English].

12. Quarantelli, E. L. (1988). Disaster crisis management: A summary of research findings. Journal of Management Studies, 25, 373-385 [in English].

13. Smith, D. (1990). Beyond contingency planning: Towards a model of crisis management. Journal of Industrial Crisis Quarterly, 4, 263-275 [in English].

14. Mitroff, I. I. (1994). Crisis management and evironmentalism: A natural fit. Journal of California Management Review, 36(2), 101-113 [in English].

15. Principles of Emergency Management (2003). Washington, DC: Emergency Management Institute [in English].

Статья посвящена обзору наработок в области кризисных коммуникаций. Осуществляется анализ основных составляющих этого понятия и исследований, которые проводились с момента возникновения кризисных коммуникаций. Первая часть посвящена анализу широкого спектра дефиниций понятия «кризисная коммуникация" и ее составных частей. Во второй части автор делает обзор наработок, которые осуществлялись в направлении исследования кризисных коммуникаций. Третья часть обращает внимание на исследования смежных понятий, связанных с кризисными коммуникациями.

В конце статьи автор анализирует этапы становления кризисных коммуникаций. В статье акцент делается на исследовании всех составляющих кризисно-коммуникационного реагирования. Обращается внимание и подробно описываются все этапы борьбы с кризисом (докризисная, кризисная и посткризисная фазы). Автор делает выводы и отмечает перспективы исследований.

Ключевые слова: кризисные коммуникации; антикризисный PR; риск-менеджмент; связи с общественностью; превентивное реагирование; анализ среды; антикризисное управление; проблемный менеджмент.

An interest in solving of crisis situations has created a dozens of research findings and the best observations practice by academics and practitioners in the disciplines of management and communication. This interest has created a cottage industry for experts on management practices. It is even a key aspect of issues management in so far as issues leading to the crisis and crisis leading to the issues.

The management reasoning for this interest is simple: the crisis costs money, which offers the incentive to avoid, 
mitigate, and respond in the best ways got protecting capital and human resources, and generically 'reputation', which may feature the essence of an effective crisis response.

Damaged reputation can offend businesses' customers, nonprofit donors and legislators, who provide tax revenue for

the government agencies. Thus, by whatever focus, the ultimate topic featured is the integrity and legitimacy of the organization, as managed resources, through various disciplines, including public relations. The author has made an analysis of investigations which has been conducted in a field of crisis communication.

Keywords: crisis communication; anticrisis PR; risk-management; public relations; preventive reacting; environment analysis; anticrisis management; problem management.

Рецензент - О. В. Тріщук, д.н. із соц. комунікацій, професор, КПІ ім. Ігоря Сікорського 